\title{
Pituitary dermoid and epidermoid cysts
}

INSERM

\section{Source}

INSERM. (1999). Orphanet: an online rare disease and orphan drug data base. Pituitary dermoid and epidermoid cysts. ORPHA:91351

Pituitary dermoid and epidermoid cysts is a rare, acquired pituitary hormone deficiency characterized by the presence of rare, benign tumor in the sellar region. Clinical presentation is either acute or insidious, and is variable according to the cyst location, size and potential rupture. Most commonly patients present with headache, visual disturbances, and pituitary dysfunction. 